\title{
HUBUNGAN KADAR LIPID DARAH DENGAN DERAJAT KEPARAHAN NEUROPATI DIABETIK PERIFER DI RUMAH SAKIT WAHIDIN SUDIROHUSODO
}

\author{
CORRELATION BETWEEN BLOOD LIPID LEVELS AND SEVERITY OF DIABETIC \\ PERIPHERAL NEUROPATHY IN WAHIDIN SUDIROHUSODO HOSPITAL
}

Devina Irawan, * Audry Devisanty Wuysang, * Yudy Goysal*

\begin{abstract}
Introduction: Blood lipid levels play a role in the etiopathogenesis of diabetic neuropathy and have a significant relationship to the severity of diabetic neuropathy in patients with diabetes mellitus (DM).

Aim: To assess the correlation between blood lipid levels and the severity of diabetic peripheral neuropathy (DPN) based on nerve conduction study (NCS).

Methods: A cross-sectional study at Wahidin Sudirohusodo General Hospital, Makassar, consecutively from December 2018 to March 2019 on type 2 DM patients with DPN based on screening for diabetic neuropathy symptoms. HbA1C and blood lipid levels were examined, and DPN severity based on NCS was assessed using electromyoneurography (ENMG) with England criteria. One-way ANOVA was used for correlation analysis.
\end{abstract}

Results: There were 56 subjects with an average age of 60.25 years old, the majority was women (51.8\%) with DM duration $\geq 5$ years (62.5\%), HbAlC levels of patients $\geq 7 \%$ (55.4\%), dyslipidemia (76.8\%), and experienced severe DPN (55.4\%). There was a significant relationship between blood lipid levels and the severity of DPN ( $p<0.05)$, especially in subjects with a patient's $\mathrm{HbA1C}$ level $<7 \%$.

Discussion: High lipid level plays a role in etiopathogenesis of diabetic neuropathy.

Keywords: Blood lipid levels, diabetic peripheral neuropathy, $\mathrm{HbAlC}$

\section{ABSTRAK}

Pendahuluan: Kadar lipid darah berperan dalam etiopatogenesis neuropati diabetik dan memiliki hubungan signifikan terhadap derajat keparahan neuropati diabetik pada pasien diabetes melitus (DM).

Tujuan: Menilai hubungan kadar lipid darah dengan derajat keparahan neuropati diabetik perifer (NDP) berdasarkan Nerve Conduction Study (NCS).

Metode: Penelitian potong lintang di RSUP Wahidin Sudirohusodo, Makassar, secara konsekutif periode Desember 2018-Maret 2019 terhadap pasien DM tipe 2 yang mengalami NDP berdasarkan skrining diabetic neuropathy symptoms. Dilakukan pemeriksaan kadar HbA1C dan lipid darah, serta penilaian derajat keparahan NDP berdasarkan KHS menggunakan alat elektromioneurografi (ENMG) dengan kriteria England. Analisis hubungan menggunakan uji one-way ANOVA.

Hasil: Didapatkan 56 subjek dengan rerata usia 60,25 tahun, mayoritas perempuan (51,8\%) dengan durasi DM $\geq 5$ tahun $(62,5 \%)$, kadar HbA1C pasien $\geq 7 \%$ (55,4\%), dalam keadaan dislipidemia (76,8\%), dan mengalami NDP berat $(55,4 \%)$. Terdapat hubungan bermakna antara kadar lipid darah dan derajat keparahan NDP $(\mathrm{p}<0,05)$, terutama pada subjek dengan kadar HbA1C pasien $<7 \%$.

Diskusi: Tingginya kadar lipid darah akan memperberat derajat keparahan NDP.

Kata kunci: $\mathrm{HbA1C}$, kadar lipid darah, neuropati diabetik perifer

*Departemen Ilmu Penyakit Saraf FK Universitas Hasanuddin, Makassar. Korespondensi: devinairwn@gmail.com.

\section{PENDAHULUAN}

Diabetes Melitus (DM) merupakan suatu kelompok penyakit metabolik dengan karakteristik hiperglikemia yang terjadi karena kelainan sekresi insulin, kerja insulin atau keduanya. ${ }^{1}$ World Health Organisation (WHO) memprediksi kenaikan jumlah penderita DM di Indonesia dari 8,4 juta pada tahun 2000 menjadi sekitar 21,3 juta pada tahun 2030 . Laporan ini menunjukkan adanya peningkatan jumlah penderita DM sebanyak 2-3 kali lipat pada tahun $2035 .^{2}$

Salah satu komplikasi DM tersering adalah neuropati diabetik perifer (NDP) yang merupakan penyebab utama disabilitas akibat ulserasi, amputasi, gangguan gait, dan cedera akibat jatuh. Sekitar 20$30 \%$ pasien neuropati diabetik perifer mengalami nyeri neuropatik. ${ }^{3}$ Meskipun kontrol glukosa darah baik, komplikasi tersebut masih sering terjadi, 
sehingga diduga terdapat faktor lain yang terlibat selain kontrol glukosa darah, antara lain dislipidemia.

Dislipidemia adalah keadaan metabolisme lipid abnormal yang ditandai dengan peningkatan kadar lipid plasma, yaitu kolesterol total dan trigliserida. Dislipidemia berperan dalam etiopatogenesis neuropati diabetika. Tingginya kadar lipid dapat menginduksi stres oksidatif pada neuron sensorik, sehingga berperan signifikan terhadap terjadinya neuropati diabetik. $^{4-5}$

NDP merupakan gejala atau tanda disfungsi saraf perifer pada penderita diabetes melitus (DM) tanpa ada penyebab lain yang melibatkan banyak saraf tepi. Distribusi gangguan ini bersifat simetris bilateral, serta meliputi gangguan sensorik dan motorik. Diagnosis neuropati diabetik perifer utama adalah berdasarkan pemeriksaan elektroneuromiografi, yang dapat diskrining menggunakan skor diabetic neuropathy symptoms (DNS). ${ }^{6-8}$

\section{TUJUAN}

Untuk menilai hubungan kadar lipid darah dengan derajat keparahan neuropati diabetik perifer (NDP) melalui nerve conduction study (NCS).

\section{METODE}

Penelitian potong lintang di RSUP Wahidin Sudirohusodo, Makassar, pada bulan Desember 2018 sampai Maret 2019. Kriteria inklusi adalah penderita DM tipe 2 berusia $\geq 35$ tahun yang mengalami NDP berdasarkan DNS, dan menyatakan tidak berkeberatan disertakan dalam penelitian.

DNS adalah kuesioner berisi 4 pertanyaan yang masing-masing bernilai 1, dengan nilai maksimal 4 . Nilai $\geq 1$ dianggap terdapat NDP. ${ }^{9}$ Kuesioner tersebut terdiri atas pertanyaan: 1) Apakah anda mengalami ketidakstabilan saat berjalan? 2) Apakah kaki dan atau jari kaki anda terasa nyeri seperti terbakar pada saat istirahat dan atau malam hari? 3) Apakah anda merasakan kaki dan atau jari kaki seperti ditusuktusuk/kram pada saat istirahat dan atau malam hari? dan 4) Apakah kaki dan atau jari kaki anda mati rasa?

Subjek dilakukan pemeriksaan darah untuk menilai HbA1C serta kadar kolesterol lengkap, meliputi kolesteraol total, trigliserida, low density lipoprotein (LDL), dan high density lipoprotein HDL. Subjek dengan kadar $\mathrm{HbA1C} \geq 7 \%$ dianggap memiliki kadar gula darah yang tidak terkontrol selama 3 bulan terakhir. Keadaan dislipidemia ditandai dengan tiga abnormalitas kadar lipid, yaitu peningkatan serum trigliserida $(>150 \mathrm{mg} / \mathrm{dL})$, peningkatan $\mathrm{LDL} \geq 100 \mathrm{mg} /$ $\mathrm{dL}$, dan penurunan $\mathrm{HDL} \leq 60 \mathrm{mg} / \mathrm{dL}$.

Adapun keparahan NDP ditentukan berdasarkan pemeriksaan elektroneurografi, yaitu kecepatan hantar saraf, sesuai dengan kriteria England. Penentuan derajat keparahan dinilai dari jumlah nilai KHS yang abnormal, baik motorik maupun sensorik, pada saraf suralis, tibialis atau peroneal, yaitu 1) ringan; terdapat 2-3 nilai yang abnormal, 2) sedang; terdapat 4 nilai yang abnormal, dan 3 ) berat; terdapat lima nilai yang abnormal. ${ }^{10}$

Data diolah menggunakan program SPSS versi 22.0. Penilaian hubungan antar variabel menggunakan uji one-way Anova bila sebaran data normal; atau uji Kruskal Wallis bila sebaran tidak normal, dengan nilai $\mathrm{p}<0,05$ dianggap bermakna.

\section{HASIL}

Didapatkan 56 subjek dengan rerata usia 60,25 tahun, mayoritas perempuan $(51,8 \%)$ dengan durasi $\mathrm{DM} \geq 5$ tahun $(62,5 \%)$, kadar $\mathrm{HbA1C}$ pasien $\geq 7 \%$ $(55,4 \%)$, dan dalam keadaan dislipidemia $(76,8 \%)$. Sebanyak $32 \%$ subjek yang merokok dan hampir separuhnya mengalami hipertensi $(46,4 \%)$.

Didapatkan sebagian besar subjek mengalami NDP berat $(55,4 \%)$ dan sedang $(25 \%)$, serta mempunyai kadar gula darah yang tidak terkontrol (HbA1C $\geq 7 \%$ ) sebesar 62,5\% (Tabel 1). Walaupun tidak bermakna, subjek dengan derajat neuropati yang berat lebih banyak ditemukan dengan kadar $\mathrm{HbA1C}$ $\geq 7 \%(62,5 \%)$ dibandingkan pada subjek dengan kadar $\mathrm{HbA} 1 \mathrm{C}<7 \%$ hanya $45,8 \%$ yang menderita NDP berat (Tabel 2).

Tabel 3 menunjukkan adanya hubungan kadar kolesterol total dengan derajat keparahan NDP. Peningkatan rerata kadar kolesterol total akan diikuti dengan perburukan derajat keparahan NDP secara bermakna $(p=0,029)$. Subjek dengan NDP derajat berat memiliki rerata kadar kolesterol total rata-rata $214,45 \mathrm{mg} / \mathrm{dL}$, sedangkan pada NDP ringan memiliki 
Tabel 1. Karakteristik Subjek Penelitian $(n=56)$

\begin{tabular}{|c|c|c|}
\hline Variabel & Jumlah & Frekuensi (\%) \\
\hline \multicolumn{3}{|l|}{ Usia } \\
\hline - $35-50$ & 8 & 14,20 \\
\hline - $51-60$ & 20 & 35,71 \\
\hline - $61-80$ & 28 & 49,99 \\
\hline \multicolumn{3}{|l|}{ Jenis Kelamin } \\
\hline - Perempuan & 29 & 51,8 \\
\hline - Laki-laki & 27 & 48,2 \\
\hline \multicolumn{3}{|l|}{ Durasi DM } \\
\hline - $\geq 5$ tahun & 35 & 62,5 \\
\hline - $\quad<5$ tahun & 21 & 37,5 \\
\hline \multicolumn{3}{|l|}{ HbA1C } \\
\hline - $\geq 7 \%$ & 31 & 55,4 \\
\hline - $\quad<7 \%$ & 25 & 44,6 \\
\hline \multicolumn{3}{|l|}{ Merokok } \\
\hline - $\mathrm{Ya}$ & 18 & 32,1 \\
\hline - Tidak & 38 & 67,9 \\
\hline \multicolumn{3}{|l|}{ Dislipidemia } \\
\hline - $\mathrm{Ya}$ & 43 & 76,8 \\
\hline - Tidak & 13 & 23,2 \\
\hline \multicolumn{3}{|l|}{ Hipertensi } \\
\hline - $\mathrm{Ya}$ & 26 & 46,4 \\
\hline - Tidak & 30 & 53,6 \\
\hline \multicolumn{3}{|l|}{ Derajat NDP } \\
\hline - Berat & 31 & 55,4 \\
\hline - Sedang & 14 & 25 \\
\hline - Ringan & 11 & 19,6 \\
\hline
\end{tabular}

Tabel 2. Proporsi Derajat Neuropati Diabetik Perifer berdasarkan kadar HbA1C $(n=56)$

\begin{tabular}{lccc}
\hline $\begin{array}{l}\text { Derajat } \\
\text { Neuropati }\end{array}$ & $\begin{array}{c}\text { HbA1C } \geq 7 \% \\
(\mathbf{n}=\mathbf{3 2})\end{array}$ & $\begin{array}{c}\text { HbA1C }<\mathbf{7 \%} \\
(\mathbf{n}=\mathbf{2 4})\end{array}$ & $\mathbf{p}$ \\
\hline Berat & $20(62,5 \%)$ & $11(45,8)$ & \\
Sedang & $7(21,9 \%)$ & $7(29,2)$ & $\mathrm{p}=0,451$ \\
Ringan & $5(15,6)$ & $6(25)$ & \\
\hline
\end{tabular}

kadar $175,36 \mathrm{mg} / \mathrm{dL}$. Hubungan tersebut lebih jelas terlihat pada subjek dengan kadar $\mathrm{HbAlC}<7 \%$ $(\mathrm{p}=0,000)$.

Adapun peningkatan kadar LDL pada subjek secara keseluruhan tidak berhubungan dengan derajat keparahan NDP $(\mathrm{p}=0,228)$. Namun pada subjek dengan kadar $\mathrm{HbA} 1 \mathrm{c}<7 \%$, didapatkan makin tingginya rerata LDL pada subjek yang memiliki derajat neuropati yang berat secara bermakna $(\mathrm{p}=0,028)$.

\section{PEMBAHASAN}

Penelitian ini mendapatkan rerata usia subjek rerata usia 60,25 tahun, sesuai dengan epidemiologi terjadinya neuropati diabetik paling sering pada usia $>50$ tahun, lebih jarang pada yang berumur kurang dari 30 tahun. ${ }^{11}$ Hal ini pula yang menyebabkan pemilihan sampel adalah berusia $\geq 35$ tahun. Neuropati perifer biasanya memengaruhi orang tua, disebabkan oleh kerusakan aksonal atau demielinasi, pada serat besar atau kecil. ${ }^{12}$

Sebagian besar subjek penelitian ini dalam keadaan dislipidemia $(76,8 \%)$, mengalami NDP berat $(55,4 \%)$ dan sedang $(25 \%)$, serta mempunyai kadar gula darah yang tidak terkontrol $(\mathrm{HbA} 1 \mathrm{C} \geq 7 \%$ ) sebesar 55,4\%. Dislipidemia adalah kontributor signifikan terhadap perkembangan neuropati diabetik melalui induksi stres oksidatif pada neuron sensorik. ${ }^{13}$ Dislipidemia menggambarkan kondisi resistensi insulin berat dan harus dikendalikan pada pasien DM tipe $2 .{ }^{14}$

Adanya resistensi insulin dan asam lemak bebas jenuh menyebabkan perubahan dalam komposisi asam lemak dari membran fosfolipid. Membran yang kaya akan asam lemak bebas jenuh menjadi lebih kaku dan menunjukkan gangguan konduksi listrik dan kapasitas yang berkurang untuk ekspresi reseptor dan transduksi sinyal yang akan menyebabkan neuropati. ${ }^{5}$

Produksi reactive oxygen species (ROS) yang dipercepat pada diabetes menghasilkan LDL teroksidasi (oxLDL) yang mengikat ke reseptor LOX1 dan mengaktifkan NADPH oksidase, memperburuk produksi ROS bahkan lebih jauh dan mempercepat perkembangan NDP. Deoksi-sfingolipid teroksidasi adalah lipid neurotoksik yang terkait dengan NDP, tetapi mekanisme kerjanya masih belum diketahui. ${ }^{5}$

Walaupun tidak didapatkan hubungan bermakna antara kadar lipid darah dengan derajat keparahan NDP pada subjek dengan kadar HbA1C $\geq 7 \%$, data penelitian ini menunjukkan pada subjek dengan kadar $\mathrm{HbA} 1 \mathrm{C} \geq 7 \%$ didapatkan $62,5 \%$ subjek menderita NDP berat, sedangkan pada subjek dengan kadar $\mathrm{HbA} 1 \mathrm{C}<7 \%$ hanya $45,8 \%$ yang menderita NDP berat. Kontrol glikemik yang buruk berhubungan dengan pembentukan advanced glycation end product-receptor advanced glycation end product (AGE-RAGE), reactive oxygen species (ROS), dan 
Tabel 3. Hubungan Kadar Lipid dengan Derajat Neuropati Diabetik Perifer

\begin{tabular}{|c|c|c|c|c|}
\hline \multirow{2}{*}{$\begin{array}{c}\text { Rerata Kadar+SD } \\
(\mathrm{mg} / \mathrm{dL})\end{array}$} & \multicolumn{3}{|c|}{ Derajat Neuropati } & \multirow{2}{*}{$\mathbf{p}$} \\
\hline & Ringan & Sedang & Berat & \\
\hline \multicolumn{5}{|l|}{ Kolesterol Total } \\
\hline - Subjek Keseluruhan $(\mathrm{n}=56)$ & $175,36+42,22$ & $204,71 \pm 34,24$ & $214,45+42,38$ & 0,029 \\
\hline - Subjek dengan Kadar HbA1C <7\% $(n=24)$ & $146 \pm 16,31$ & $196 \pm 33,54$ & $221,55 \pm 29,87$ & 0,000 \\
\hline \multicolumn{5}{|l|}{ LDL } \\
\hline - Subjek Keseluruhan $(n=56)$ & $105,09 \pm 36,64$ & $113,14 \pm 34,46$ & $126,61 \pm 39,99$ & 0,228 \\
\hline - Subjek dengan Kadar HbA1C $<7 \%(n=24)$ & $89 \pm 21$ & $110+34$ & $134+31$ & 0,028 \\
\hline \multicolumn{5}{|l|}{ HDL } \\
\hline - Subjek Keseluruhan $(\mathrm{n}=56)$ & $53 \pm 14.73$ & $57,43+22.28$ & $51,84 \pm 19,35$ & 0,548 \\
\hline - Subjek dengan Kadar HbA1C <7\% $(n=24)$ & $53,33 \pm 16,30$ & $62,86 \pm 20,44$ & $57,91 \pm 21.90$ & 0,505 \\
\hline \multicolumn{5}{|l|}{ Trigliserida } \\
\hline - Subjek Keseluruhan $(n=56)$ & $136,91+57,02$ & $163,93 \pm 85,6$ & $145.03+49$ & 0,652 \\
\hline - Subjek dengan Kadar HbA1C <7\% $(\mathrm{n}=24)$ & $103 \pm 21$ & $161 \pm 65$ & $143 \pm 57$ & 0,157 \\
\hline
\end{tabular}

kerusakan endotel, sehingga akan memperberat derajat keparahan kerusakan saraf pada NDP. Hal ini ditemukan pada penelitian Sakasasmita dkk adanya hubungan bermakna antara kadar HbA1C dengan derajat keparahan NDP $(\mathrm{p}<0,0001) .{ }^{15}$

Penelitian ini menunjukkan hubungan yang bermakna antara kadar kolesterol total dengan derajat keparahan NDP $(\mathrm{p}=0,029)$. Kadar kolesterol total akan lebih tinggi pada NDP berat dibandingkan dengan NDP sedang dan ringan. Hal ini sesuai dengan Yadav dkk bahwa penderita DM dengan normolipidemia memiliki kadar kolesterol total $183,4 \pm 9,25 \mathrm{mg} /$ dL serta KHS nervus suralis dan tibialis posterior $41,68 \pm 1,29$ mdet dan $46,34 \pm 0,88$ mdet. KHS ini menurun secara signifikan pada penderita DM dengan hiperlipidemia (kadar kolesterol total $207,21 \pm 11,02 \mathrm{mg} / \mathrm{dL}$ ) menjadi $39,93 \pm 1,55 \mathrm{mdet}$ dan $44,57 \pm 0,96 \mathrm{mdet}$ pada nervus suralis dan tibialis posterior. ${ }^{4}$

Adanya resistensi insulin dan asam lemak bebas jenuh menyebabkan perubahan dalam komposisi asam lemak dari plasma membran fosfolipid. Membran yang kaya akan asam lemak bebas jenuh menjadi lebih kaku dan menunjukkan gangguan konduksi listrik dan kapasitas yang berkurang untuk ekspresi reseptor dan transduksi sinyal sehingga memperburuk NDP. ${ }^{5}$

Pada penelitian ini juga dilihat hubungan kadar lipid darah dengan derajat keparahan NDP berdasarkan HbA1C untuk lebih memperjelas hubungan antar variabel. Pada subjek dengan kadar gula darah yang tidak terkontrol $(\mathrm{HbA} 1 \mathrm{C} \geq 7 \%$ ) menunjukkan hubungan yang tidak bermakna antara kadar lipid dengan derajat keparahan neuropati. Hal ini disebabkan karena kadar $\mathrm{HbA1C}$ yang tidak terkontrol akan saling merancu dengan tingginya kadar lipid darah yang sama-sama memperparah derajat NDP.

Kadar lipid darah (kolesterol total dan LDL) subjek dengan kadar gula darah yang terkontrol (HbA1C <7\%) berhubungan bermakna dengan derajat keparahan NDP. Hal ini disebabkan karena kadar lipid darah subjek dengan HbA1C terkontrol memberikan pengaruh yang lebih besar terhadap derajat keparahan NDP dibandingkan dengan kadar gula darah. Oleh karena itu, selain HbA1C, kadar lipid juga harus dikontrol pada pasien dengan DM tipe 2 untuk mencegah terjadinya progresifitas NDP.

Keterbatasan penelitian ini adalah kurangnya pertanda biokimia lain seperti penilaian keadaan aterogenik dan pemeriksaan small density LDL serta tidak meneliti komponen KHS secara spesifik. Penelitian ini juga tidak menggunakan analisis multivariat untuk memastikan $\mathrm{HbA1C}$ sebagai merupakan faktor perancu, oleh karena Sakasasmita dkk telah mendapatkan hubungan antara derajat keparahan NDP dengan HbA1C, sehingga dianggap tidak perlu dilakukan analisis ulang. 


\section{KESIMPULAN}

Terdapat hubungan antara kadar lipid darah dengan derajat keparahan NDP pada penderita DM tipe 2. Pada kadar glukosa darah yang terkontrol (HbA1c $<7 \%$ ) didapatkan hubungan yang bermakna antara kadar lipid darah dengan derajat keparahan NDP pada penderita DM tipe 2. Pada kadar glukosa darah yang tidak terkontrol ( $\mathrm{HbA} 1 \mathrm{C} \geq 7 \%$ ), tidak terdapat hubungan antara kadar lipid darah dengan derajat keparahan NDP pada penderita DM tipe 2.

\section{DAFTAR PUSTAKA}

1. PERKENI. Pengelolaan dan pencegahan diabetes melitus tipe 2 di Indonesia 2015. PB Perkeni; 2015.

2. Sungkono R. Hubungan antara profil lipid darah dengan terjadinya neuropati diabetikum pada penderita diabetes melitus tipe 2 di RSU Kota Tangerang Selatan tahun 2013-2015 [skripsi]. Jakarta: Universitas Islam Negeri Syarif Hidayatullah; 2016.

3. Sadosky A, Mardekian J, Parsons B, Hopps M, Bienen, Markman J. Healthcare utilization and cost in diabetes relative to the clinical spectrum of painful diabetic peripheral neuropathy. J Diabetes Complication. 2015;29:212-7.

4. Yadav N, Shete A, Yadav P, Nisha Y, Khan ST. Study of nerve conduction velocity in type II diabetes mellitus. Natl Integr Res Med. 2015;6(4):36-43.

5. Perez-Matos MC, Morales-Alvarez MC, Mendivil CO. Lipids: a suitable therapeutic target in diabetic neuropathy. J Diabetes Res. 2017:2017:4-6.

6. Callaghan BC, Cheng H, Stables CL, Smith AL, Fielsman EL. Diabetic neuropathy: clinical manifestations and current treatments. Lancet Neurol. 2012;11(6):521-34.
7. Dixit S, Maiya A. Diabetic peripheral neuropathy and its evaluation in a clinical scenario: a review. J Postgraduate Medicine. 2014;60:33.

8. Charnogursky GA, Emanuele NV, Emanuele MA. Neurologic complications of diabetes. Current Neurol Neurosci Reports. 2014;14(7).

9. Yang Z, Chen R, Zhang Y, Huang Y, Hong T, Sun F, Ji L, Zhan S. Scoring systems to screen for diabetic peripheral neuropathy. Cochrane Database of Systematic Reviews. 2014;3;3-18.

10. England JD, Gronseth GS, Franklin G, Miller RG, Asbury AK, Carter GT, dkk. Distal symmetrical polyneuropathy: a definition for clinical research: report of the American Academy of Neurology, the American Association of Electrodiagnostic Medicine and the American Academy of Physical medicine and Rehabilitation. Neurology. 2005;25;64(2):199-207.

11. Subekti I. Buku Ajar Ilmu Penyakit Dalam. Jilid III Edisi V. Jakarta: Fakultas Kedokteran Universitas Indonesia; 2009. h. 1947-4.

12. Popescu S, Timar B, Baderca F, Simu M, Laura D, Velea I, dkk. Age as an independent factor for the development of neuropathy in diabetic patients. Clin Interv Aging. 2016;11:313-8.

13. Yadav DN, Khan DS. Effect of hyperlipidemia on nerve conduction velocity in type II diabetes mellitus. IOSR J Dental Medical Sci. 2014;13:07-9.

14. Cho YN, Lee KO, Jeong J, Park HJ, Kim S, Shin HY, dkk. The role of insulin resistance in diabetic neuropathy in Koreans with type 2 diabetes mellitus: a 6-year follow-up study. Yonsei Med J. 2013;55(3):700-8.

15. Sakasasmita S. Hubungan kontrol glikemik dan durasi diabetes mellitus dengan derajat keparahan diabetic symmetrical polyneuropathy [tesis]. Makassar: Universitas Hasanuddin; 2017. 